\title{
Around the Library Table With Luther A. Brewer: Annual Reflections on Collecting Leigh Hunt
}

ROBERT A. SHADDY

During the late nineteenth and early twentieth centuries, American collectors of rare books and manuscripts assembled collections which were stunning in their scope and content. The activities of millionaires such as Henry E. Huntington, J. Pierpont Morgan, Henry Clay Folger, and others have justified the characterization of the era as the "Golden Age" of book collecting in America. Fortunately, most of these dazzling private libraries were preserved by being donated or sold to institutions. The long-term impact, of course, has been that scholars from both sides of the Atlantic (and, indeed, throughout the world) have tremendously benefited by having excellent literary and historical resources available for their use. Most researchers, furthermore, have been quick to acknowledge the role played by collectors in the enhancement and improvement of the nation's library resources. ${ }^{1}$

${ }^{1}$ For example, Louis B. Wright, historian and librarian of the Huntington and Folger libraries, wrote in 1954 that "the devoted book collectors of our country have contributed enormously to the cultural development of the nation and they have made possible scholarship and learning which we could not have had without their libraries. They deserve to rank with the founders of colleges and universities as public benefactors." Book Collectors and Scholarship (Minneapolis: University of Minnesota Press, 1954), 67; see also Louis B. Wright and Gordon N. Ray, The Private Collector and the Support of Scholarship (Los Angeles: University of California, Los Angeles, 1969). A number of studies are available which discuss the activities of collectors during the period. See, for example, Carl Cannon, American Book Collectors and Collecting: From 
However, the "book collecting game" was not only a pastime for multimillionaires; many individuals from the middle and upper classes participated and derived a great deal of personal satisfaction from collecting rare books and manuscripts. Many collectors of the era wrote and published reminiscences and recollections which help in determining their motives for spending a great deal of money, time and energy on their "hobbies." One rapidly discovers that collectors were mainly governed by sentiment and emotion and did not purchase books for investment purposes or to ease status anxiety. In an era of rapid and disorienting cultural, technological and political change, collecting allowed the recovery of an idealized past which collectors believed had slipped or was slipping away from them. As the result of a "sentimental communion" with the collection, they could, it seems, freely roam through the past. In a modernizing world, inanimate objects served as a therapeutic coping mechanism for some members of the middle and upper-classes. ${ }^{2}$

This interpretation of collectors and collecting can be tested by focusing upon the collecting career of Luther Albertus Brewer whose premier collection of Leigh Hunt and his circle of literary friends was eventually acquired by the University of Iowa. His writings reveal a man who loved books, reading, and handling original first editions, manuscripts and letters. The associations they evoked were sentimental and emotional.

Colonial Times to the Present (New York: H.H. Wilson, 1941); Hellmut Lehman-Haupt, The Book in America: a History of the Making, the Selling and the Collecting of Books in the United States (New York: Bowker, 1939); John Carter, Books and Book Collectors (London: Rupert Hart-Davis, 1956) and Taste and Technique in Book Collecting (London: Private Libraries Association, 1970).

${ }^{2}$ For further remarks on this interpretation of book collecting, see Robert Alan Shaddy, "'A Mad World, My Masters!': Book Collecting in America, 1890-1930" (Ph.D. diss., University of Missouri, 1990). My views on the late nineteenth and early twentieth centuries have been shaped largely by several works of intellectual and cultural history including Stephen Kern, The Culture of Time and Space, 1880-1918 (Cambridge: Harvard University Press, 1983); Cecelia Tichi, Shifting Gears: Technology, Literature, Culture in Modernist America (Chapel Hill: University of North Carolina Press, 1987); Alan Trachtenberg, The Incorporation of America: Culture and Society in Gilded Age America (New York: Hill and Wang, 1982); and Jackson Lears, No Place of Grace: Antimodernism and the Transformation of American Culture, 1880-1920 (New York: Pantheon, 1981). 
Indeed, for this Iowan, the collection served as a reminder of and a link to the past which was being irrevocably altered by disquieting change.

Living a life that spanned the years from the Civil War to the Great Depression, Luther A. Brewer was born in Welsh Run, Pennsylvania on December 17, 1858 and died at the age of 74 on April 28, 1933 in Cedar Rapids, Iowa. In 1934, his extensive collection of rare books, manuscripts and letters related to Leigh Hunt (1784-1859) and Hunt's literary circle was acquired by the University of Iowa. The Hunt collection represented virtually a lifetime of association with collecting and reading. Early in his life, Brewer became interested in books and collected English literature, fine printing and association copies. In 1920 he admitted to becoming a "victim of the bookcollecting 'bug"' while attending grammar school in Maryland. It was his "good fortune" to have a teacher who was a genuine lover of literature. After reading Dickens' Pickwick Papers, Brewer "was soon as steeped in Dickens as David Copperfield was in his love for Dora." Being unable to afford a bound set of the novelists' works, Brewer settled for a cheap popular edition which cost only a few pennies. He recalled, "No thrill of book-collecting joy has ever come to me in later years that exceeded the happiness that was mine when the mails brought me a large package of the stories of Dickens in this inexpensive form." Around this same time, Brewer acquired and also sentimentally valued a cheap, paper-bound edition of the works of Shakespeare. Reflecting back, in 1920, he spent "many a glorious summer afternoon in the shade of an old apple tree, with this Precious volume as my sole companion." For Brewer, collecting "has meant much to one who ever has been compelled to labor day and night." 3

${ }^{3}$ Luther A. Brewer, "The Delights of a Hobby: Some Experiences in BookCollecting," in Nineteenth Century Yearbook of the Bibliophile Society (Boston: Bibliophile Society, 1920), 55-57. On Brewer's life, see Luther A. Brewer, My Leigh Hunt Library: Collected and Described by Luther A. Brewer (Cedar Rapids, IA: Torch Press, 1932), vii-xxxvii; Frank S. Hanlin, "The Brewer-Leigh Hunt Collection at the State University of Iowa," Keats-Shelley Journal 8 (Autumn 1959), 91-94; Donald C. Dickinson, Dictionary of American Book Collectors (New York: Greenwood Press, 1986), 50-51. 
After graduating from Gettysburg College in 1883, Brewer migrated to Iowa. The most significant and valuable part of his baggage, to him, was the box of books which represented the collections of his youth. Indeed, for the collector, Brewer believed, "first loves are lasting." And Brewer loved the whole ethos of collecting. What, he asked, was more satisfying to the book lover than browsing in an old book shop? No "genuine lover" could pass up any such opportunity. The book shop's "very aroma" appealed to him as did the "disordered piles of printed matter." The possibility of "finds" drew him "irresistibly." According to Brewer, "The joys of a collector come through the pursuit no less than possession. Item by itemhunting in out of the way places-suddenly and unexpectedly finding a gem in a rubbish pile; making mistakes, yes, but that only adds to the human side of the search." 4

It was Brewer's opinion that collectors should specialize in order to gain the keenest pleasure from the hobby and they needed to take an active role in building the collection, aim towards collecting along definite lines and strive for completeness. Therefore, collectors needed to possess some knowledge regarding their specialty. He chose to focus on the English author Leigh Hunt and, eventually, his group of friends (including Lamb, the Brownings, Byron and Keats). Why Leigh Hunt? Brewer usually responded, "Why not?" However, there were good reasons. Leigh Hunt, although not considered one of the great English writers of the early nineteenth century, is considered one of the period's most important literary figures. He was a lover of books and a close friend of Shelley, Keats, Lamb, and Byron. Importantly, from a practical point of view, when Brewer entered the "chase" for Hunt items the works were reasonably priced as well as obtainable. Brewer, though, felt a sentimental attachment and collected Hunt "partly because of a sympathetic feeling I possess for a fellow-lover of books...."

${ }^{4}$ Brewer, "The Delights of a Hobby," 59.

${ }^{5}$ Ibid., 65, 68-69; Donald C. Dickinson, Dictionary of American Book Collectors, 50-51. 


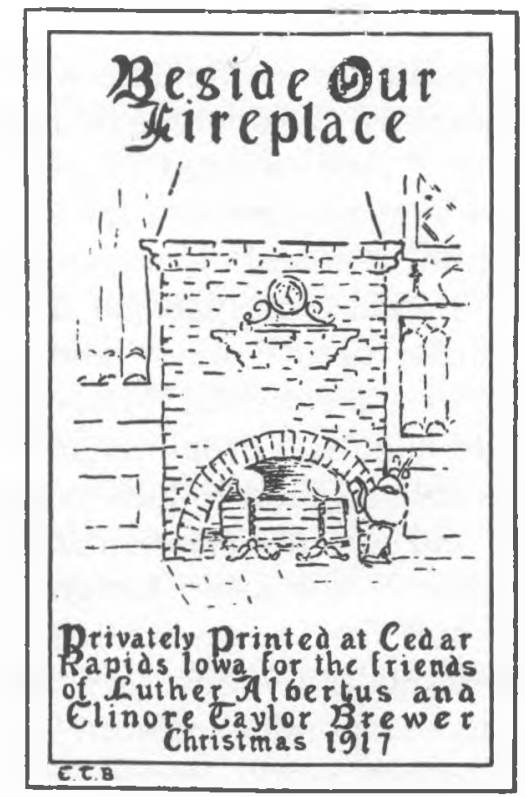

Each Christmas, beginning in 1912, Brewer issued a privately printed book which was drawn from materials from his library collection. These books (usually only about two hundred were printed) were presented to his friends and, fortunately, have been preserved by libraries and other institutions. They serve as an excellent source for recovering the motives of collectors during the late nineteenth and early twentieth centuries. His Christmas books reveal Brewer's bibliophilia, his idealization of Leigh Hunt's literary world, and his dissatisfaction with modern American culture and society. ${ }^{6}$

In Beside Our Fireplace (1917), Brewer describes the atmosphere evoked by the fireplace which should be in every book lover's reading room with the seasons also playing an important aesthetic role. Winter (unlike summer, which was more

${ }^{6}$ On the history of the Torch Press, Brewer's role regarding it and a bibliography of "Torch Press Christmas Series (1912-1959)," see Thomas L. Carney and Joyce Crawford, "The Torch Press: a Preliminary History," Books at lowa 21 (November 1974), 3-25. 
suitable for lighter reading) was the time when "those things which feed and strengthen the soul are demanded, the books that are worth while." And, a good fireplace rather than a reading lamp was a vital requirement for the reader of such books during the cold, demanding winter months in Iowa. Brewer believed the fireplace purified the air in the room and took "away the worries of the mind" and made for "good feeling, for ease, physical and mental." The collector's fireplace provided much more than heat or illumination.

The fireplace was always good to look at because it varied, was unpredictable, and was not standardized. It presented a "charming picture, never the same tonight that it was last night, changing to suit the whims of those in front of it." Unlike the symbols of modern, industrial society (for example, the stove), the fireplace responded to nature and human nature and was part of an organic world. Brewer offers his view:

The fire on the hearth is in a sort of self-satisfied mood. It lacks fighting spirit except at infrequent intervals when an unusual amount of moisture drops down the chimney. Then there is a brief but not very energetic complaint.

It behaved differently last night. Then the elements out of doors were belligerent, the winds were turbulent and noisy. Those disturbances aroused the fighting spirit of the fire, and tongues of flame were sent up the chimney, either in protest to the turmoil outside or in sympathy with it, depending upon the mood or point of view of the one seated in front of the hearth. ${ }^{7}$

The book collector's fireplace facilitated trips back in time and across space. Often, Brewer imagined himself transported to the days of his youth. Looking at his own hearth reminded him of the great fireplace in his family's home, which included the great hickory logs, the singing kettle, delicious apples, chestnuts, even potatoes, "and the youngster [Brewer himself] by its side or sprawled on the floor in front, come back in reminiscent moments." Of course, also returning to the collector in these

${ }^{7}$ Luther A. Brewer, Beside Our Fireplace (Cedar Rapids, IA: Torch Press, 1917), 
moods was the "best of all mothers on earth . . . sweetest and fairest of all, watching, tending, caressing, loving." Brewer's sentimental fireplace also enabled him to travel in his mind "to a dark corner of the Mermaid" where he could listen to the discourse of Shakespeare, Ben Jonson, Beaumont and Fletcher. With the fireplace stimulating the imagination, one might "look in upon a session of the Literary Club, and listen to Johnson, Garrick, Burke, Sir Joshua Reynolds, Goldsmith. What talk we may hear there!" For Brewer, collecting represented much more than the accumulation of rare books and manuscripts. The items associated with the collection, for example, the fireplace, made possible a sentimental idealization of a lost world; the fireplace was "the place for soulsweetening reflection." According to Brewer, "Beside our fireplace cares cannot come into the dream-land where we exist.... One's fireplace is indeed a spot where one may become sentimental and reminiscent. It is not a spot where one may call up visions of the future. There he rather recalls the past."8

In Around the Library Table: An Evening With Leigh Hunt, published and distributed for Christmas 1920, Brewer referred again to the "cheerful fireplace" and his belief that he could better exist in a "perturbed world" (after the First World War) when his evenings could be spent in his library "with books and letters and etchings as our helpful companions." Most of this volume presents Brewer's feelings about collecting Leigh Hunt. He described how he began his collection of first editions of Hunt before the outbreak of the Great War. From time to time he was able to add to the collection Hunt's autograph letters. The collection continued to grow until, by 1920, Brewer was able to report only the rarest of Huntiana were lacking and the Brewer library had become "consecrated to Hunt." Reflecting on the English author and his appeal, Brewer perceived Hunt as a "genial fireside companion" who was fond of books. Books were considered to be "friends on the shelves" who were ever steadfast and loyal. According to the collector,

${ }^{8}$ Ibid., 9, 17-19, 21-22, 27. 
"These books of ours never dispute with us when we be weary, never tire us with small-talk. There is complete harmony at all times. Among them are friends for every mood; we are never alone when in the library." 9

The private library-study provided many vicarious pleasures for the collector. Brewer could read about fishing and go fishing even though the waters might be frozen over, for example. The library permitted him to take all sorts of vacations and to work at various pursuits. As he noted: "All things are possible to him who has surrounded himself with books..." However, the books that Brewer surrounded himself with were not recent publications, or even those printed within the last quarter century. The books found in the "modern circulating library" possessed no special interest to the true book lover. Rather, a bibliophile paid closest attention to the treasures found on a shelf or in a case which were bound in "ancient calf or vellum."

Reverently he approaches that treasury of books; tenderly and lovingly he takes out volume after volume and eagerly examines each title-page and colophon. Visions are his, glimpses of other days and other places. His soul is thrilled. He pictures the times in which these precious jewels were being produced. He feels himself akin to author and printer. He pictures the hopes and the fears of all those concerned in the making of these old volumes. Yea, verily, in every old volume there is a spirit hidden. ${ }^{10}$

For Brewer and other collectors, the "pleasures of possession" were considerable because the collection helped forestall the uncertainties of the future. This helps explain the intense emotional feelings which collectors demonstrated towards their collections. When Brewer acquired Leigh Hunt's Wit and Humour, Selected From the English Poets, a copy which was a unique presentation item from Hunt to Mary Shelley, he "felt a thrill in my heart akin to that which agitated me when I discovered the life companionship of Mrs. B[rewer]. Every fiber of my body was agitated." To close his 1920 Christmas book,

${ }^{9}$ Luther A. Brewer, Around the Library Table: An Evening With Leigh Hunt (Cedar Rapids, IA: Torch Press, 1920), 6, 8-11.

${ }^{10}$ Ibid., 11-13. 
Brewer noted, "it is pleasant to know that the past cannot be taken away. These gatherings around the lamp and by the fire, the messages of friends to friends at this hallowed time are ours." 11

In 1923, Brewer presented to his friends at Christmas The Love of Books which consisted mainly of a reprint of Hunt's essay "My Books." In his introductory remarks, the collector provided more insight on his own feelings for books and the great satisfaction that collecting and reading them gave him. The Love of Books pays homage to Hunt's unabashed bibliophilia and features Hunt's expressed wish (as revealed at the end of "My Books") that he might end his life with his head resting upon a beloved volume. Brewer idealized and treasured Hunt for this and because he saw Hunt as a "very glutton of books". Hunt provided the most striking example of the individual who lived his life for books. Brewer admiringly noted, "Given books and the opportunity of reading them, and what did it concern him that there was lack of bread and meat in the house, and the 'Executioner' was at the door." 12

Also appealing to Brewer in Hunt's essay, "My Books", was the author's description of his library-study which included his table of books piled-high at his back, his writing desk and book shelves on either side of him, and a warm fire at his feet. For the book-lover of the early twentieth century, it was a picture that was quite pleasing; or, in Brewer's mind, a "comfortable situation." With the warm ambience of the bookman's studylibrary, the act of reading and the resulting (and required) contemplation was easily realized. Even in the "swiftly moving days of the radio and the air ship" none should be too busy to become acquainted with the "choice spirits of other times."

In fact, Brewer believed that all homes should contain books; a home without books was not a true home. The book-less house was "merely a place in which to stay over night, or on a rainy day, or a stormy evening." The addition of a few books

\footnotetext{
${ }^{11}$ Ibid., 15-16, 42.

${ }^{12}$ Luther A. Brewer, The Love of Books (Cedar Rapids, IA: Torch Press, 1923), 5.
} 
made an abiding place out of rooms with cheap furniture and rag carpets; luxurious furniture without books "make a place it is good to stay away from." Brewer did not claim that books were made for furniture, "but nothing else so beautifies and embellishes a home." Books provided a therapeutic as well as an aesthetic function. He wrote, "We prefer a home filled with books rather than with furniture. We will take both if we can, but at all events we want the books.... In books we lose ourselves and all our cares." 13

Like Leigh Hunt, Luther A. Brewer loved books for their contents but there was also a sensual element involved in the "hobby" of collecting and paying homage to a preferred author. Collectors loved the sight of fine bindings on the books they collected. They also loved feeling and handling the bindings. In an interesting analogy, Brewer explained, "We love our wives or admire other beautiful women ... the more if they are neatly and becomingly dressed. Love and admiration grow cold when their objects are slatternly and raggedly clothed." The collector makes clear, though, that one cannot pay attention only to the outward appearance of a book. No matter how beautifully it is bound, it must still be read to be completely appreciated by the book-lover. The collector believed, "We lovers of books are not in sympathy with the man ... who was so much occupied with the polishing of his bindings that he had not the leisure to make himself familiar with the contents of his beloved volumes." 14

In his 1924 Christmas book, Some Lamb and Browning Letters to Leigh Hunt, Brewer meditates upon the literary and personal friendship of the three writers. Offering several letters from his collection written by these literati, Brewer illustrates their friendship and illuminates their personalities (or, rather, his perception of their personalities). He believed that a man's correspondence revealed what was really in his mind. Importantly, this belief mirrors what other collectors thought during

${ }^{13}$ Ibid., 6-8.

${ }^{14}$ Ibid., 9. 
the late nineteenth and early twentieth centuries and accounts in part for the popularity of collecting autograph letters. Letters were sincere reflections of a person. "Letters tell the story of a man's life in a superior way. They are better than the accounts of his friends, for the pen writes what the heart speaks. They give a true picture, and are to be relied upon." 15

Brewer declared his opinion of the first half of the nineteenth century as a Golden Age of English literature. Poets such as Keats, Shelley, Byron, Wordsworth and Tennyson and prose writers including Dickens, Thackeray, Landor, Hazlitt, Lamb and Hunt made the era memorable. In considering his perception of the period as being vastly superior to contemporary times, in terms of literature, Brewer conceded, "Perhaps the fault is ours, in that we view the things that have been through enlarged glasses, while the things that are, being familiar, fail vividly to impress us." 16 The collection served as a link to a past which was seen as being far more noble than the modern times of the 1920s. It linked collector and writer and became a considerable symbolic package which enabled the transcending of time and space.

To demonstrate this further, one should consider Brewer's Christmas publication for 1925, Wanderings in London, and his view of the "capital" of the book-world with its mighty sentimental associations. Through the years, Brewer and his wife visited many of the important cities of the United States and Europe. London, though, was the most charming and fascinating place. He wrote, "It grips us with a mighty hold. Once in it, we are loath to go away from it." Because he was so fond of London, the return trip to the United States was always sobering and full of sadness. He cherished the city in the quiet

\footnotetext{
${ }^{15}$ Luther A. Brewer, Some Lamb and Browning Letters to Leigh Hunt (Cedar Rapids, IA: Torch Press, 1924), 13. On the belief that letters sincerely reflected a person's true beliefs, see Thomas F. Madigan, Word Shadows of the Great: the Lure of Autograph Collecting (New York: Frederick A. Stokes, 1930) and Simon Gratz, A Book About Autographs (Philadelphia: William J. Campbell, 1920).

${ }^{16}$ Ibid. , 6.
} 
of the early morning, in the busy hours of the day and in the evening. He loved its streets and shops with "as deep a love as Charles Lamb ever had."17

During one visit to the great city, a seaman's strike required the Brewers to spend an extra month in England. The strike was a perfect excuse to linger in the "seductive Metropolis." Brewer browsed and purchased in the great bookstores of London and explored the places which held great associational interest, the "odd nooks and corners and narrow lanes and streets in the older portions" of the city. To navigate these older parts of the city, Brewer utilized Leigh Hunt's The Town (1848). Despite changes in the local topography since Hunt's time, Brewer noted, "one will not find it a difficult matter to follow Hunt as he proceeds...." According to Brewer, Hunt "saw with a seeing eye and a sympathetic and knowing spirit." Hunt, in The Town, made Samuel Johnson, Oliver Goldsmith and others "seem very real and near". It was especially charming to be in London "where the opportunities are so many for reminiscing in quiet retreats once familiar to the poets and songsters and men of affairs of other times." 18

Of course, for a collector such as Brewer, London's most immediate attraction was its many old book shops. When in the city, his first priority was to systematically check favorite sites. In an aside, Brewer confided to his readers, "We need not tell one of our kind that visiting of this sort was a joy." One of his favorite shops was in an area almost inaccessible to modern London's transportation network. The owner of this particular shop was keenly aware of its associations. Ben Jonson once lived on the site where the shop was located. A block away was the residence of Samuel Johnson. Nearby were Fleet Street, Chancery Lane and Fetter Lane "with all their memories." The

\footnotetext{
${ }^{17}$ Luther A. Brewer, Wanderings in London (Cedar Rapids, IA: Torch Press, 1925), 5-6; for another Christmas publication which treats a visit to France and its literary associations, see Brewer's Golden Days in France (Cedar Rapids, IA: Torch Press, 1927). Other collectors also idealized London, see, for example, William Roberts, The Book Hunter in London (London: Elliot Stock, 1895); and E.V. Lucas, A Group of Londoners (Minneapolis: Privately Printed, 1913).

${ }^{18}$ Brewer, Wanderings in London, 8, 10.
} 
dealer once asked Brewer, "Do you think that these things do not make a difference to me? No, I shall not move from this location until summoned to quit life."19

After browsing in the old book shops, Brewer roamed the historic places which sentimentally appealed to him. He was brought closer to his literary interests through his rambles. For example, his discussion of the Lincoln's Inn Fields and Gray's Inn illuminates their connections to the lives of Ben Jonson, Samuel Johnson, Macaulay, Dickens, Thackeray, John Bradshaw, Bacon, and others. Charles and Mary Lamb lived in the neighborhood of the Inns and the Elia essays often mentioned them. Brewer described the Lambs' quarters and recalled the visitors who came there: Hunt, William Hazlitt, the Godwins, and others, who "gathered here on Wednesday evenings, and what a company!" Brewer pictures the scene by infusing it with an abundance of sentimental domesticity. "The furniture was old, the books Lamb had sacrificed for and which he loved were 'ragged veterans'. The mahogany table was made ready, and on the sidetable were the cold meats and the hot roasted potatoes; and the 'vast jug of porter' was from Fleet Street's 'best tap.'

This description is made even more compelling when Brewer informs his readers that the building in which the Lambs lived had been razed several years ago. Merely visiting the spot where they once lived was enough to discharge a profusion of associational sentiments. He had "only the shadow, not the substance," but that was all that was needed for this collector who was bent on Yuletide reflections. "Need I again to remark," he wrote, "what joy to wander amid such scenes and to recall the days that are no more, and the like of which never will come to us." 21

In his Wanderings, Brewer described a walk which resulted in the unexpected discovery of "the humble grave of Oliver Goldsmith." Nearby was where the poor "unfortunate" writer

\footnotetext{
${ }^{19}$ Tbid., 12, 22.

${ }^{20}$ Tbid., 26-27, 29, 32-33.

${ }^{21}$ Ibid., 36.
} 
died. Also discussed was the Cheshire Cheese Inn, still in existence in 1925. Brewer could see "as in the time when Johnson and his friends met there for their night-revels." The thrill of going to London was in visiting these places. Brewer, imbued "with a fondness for the writings of Keats and Hunt", wondered "what more natural, while spending a holiday in London than to visit some of the places made notable by their presence"? Several trips of homage were made to Hampstead, site of the Keats Memorial. For Brewer, the Memorial was a "holy place" and a "shrine at which every lover of Keats may pay devotion." Although the shrine, when the collector visited it, did not contain many relics of the poet, there were enough "to interest any Keats lover and to make a visit there one not to be forgotten. To [me] the place is a hallowed spot." 22

Near the Keats Memorial was Leigh Hunt's cottage. To Brewer, it was just as it was when Hunt and his family lived there in the early nineteenth century. This was the place where Hunt spent some of the happiest years of his life and also where he endured sickness and poverty. Brewer wrote of the beautiful morning (as he would always remember it) when he visited Hunt's grave. In the same cemetery, John Forster was buried-Hunt's friend as well as Dickens'. Another treasured house was the one in which Carlyle lived and worked. Concluding his 1925 Christmas book, Brewer sighed, "These are some of the things seen and mused over in dear old London." 23

Brewer's Christmas book for 1928 was The Joys and Sorrows of a Book Collector. This publication began by describing book collectors as an "odd tribe" who are in a class by themselves and who took pride in their possessions. In fact, many boasted and acted immodestly about their successful efforts in assembling good collections: "We confess it, but why should we hide under a bushel the fact that we possess something uniquesomething which no one else has or can have until we are ready to relinquish ownership?" In The Joys and Sorrows of a Book

\footnotetext{
${ }^{22}$ Ibid., 36-38, 40.
}

${ }^{23}$ Ibid., 49-60. 
Collector, Brewer was ready to discuss his triumphs and his failures in developing his Leigh Hunt collection. He opened with the "tragedy" of a failure to secure a desired item. ${ }^{24}$

The tragedy lay in his not acting fast enough to purchase an important Leigh Hunt letter when it was offered to him by the autograph dealer, Thomas F. Madigan. Finally, after a thorough and considerable review of his financial situation (and consultation/negotiation with his wife!), Brewer decided to forego a new suit in order to purchase the letter. Thus, he recalled the example of Charles Lamb, who was happy to wear his threadbare black suit a little longer so that he might be able to afford another "ragged veteran" for his collection. Brewer, the collector of Hunt and Lamb, was "determined to emulate his example." Unfortunately, Brewer had decided for the item too late-another collector was victorious. This gentleman, wrote Brewer, "had stolen from me a great treasure." $\mathrm{He}$ tracked down and confronted his rival but "earnest begging" failed to secure the letter and its "non-possession [was] a tragedy in my collecting experience." Displaying his great sentimental attachment to his collection, Brewer asked, "What care I for the millionaire's lengthened life and his doubled pleasures, for has he not by his book activities deprived me of the pleasures of possession of certain coveted items for which my soul has panted?"25

In the world of the book collector, not all was as it seemed. Some acquisitions brought pleasant surprises. For example, at the 1920 sale of a portion of H. Buxton Forman's library, Brewer purchased a Hunt autograph letter (dated 1822) and discovered that it had been composed by Hunt but was actually written by Mary Shelley who was copying for him at the time. The letter was intended for Byron but was never sent. To show his high regard for the item and its abundant associational value, the collector had it bound in "a handsome dress of red levant, with gold letters." Brewer also acquired at the Forman sale what he

\footnotetext{
${ }^{24}$ Luther A. Brewer, The Joys and Sorrows of a Book Collector (Cedar Rapids, IA: Torch Press, 1928), 7.

${ }^{25}$ Ibid. , 9, 12, 14-15.
} 


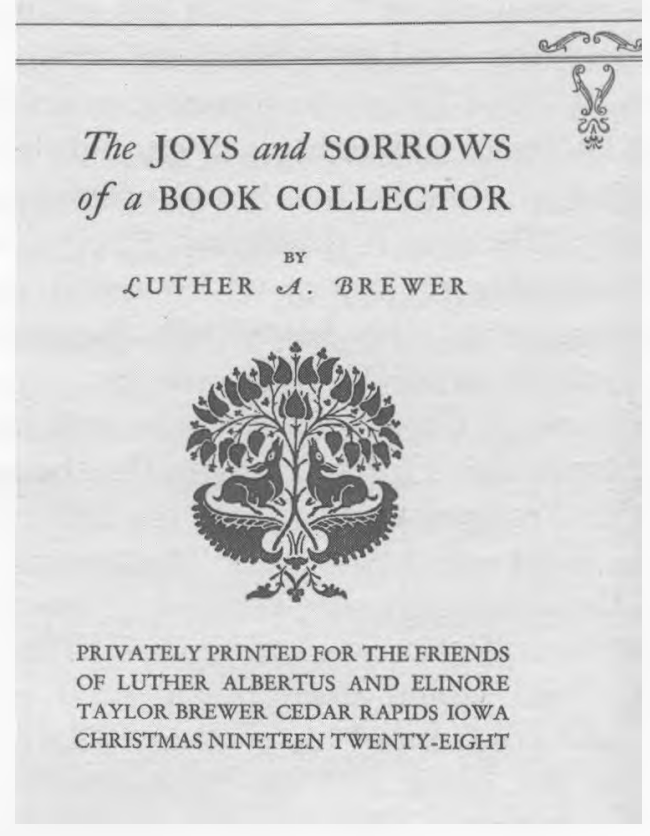

thought was a Leigh Hunt original manuscript, "The Heir of Mondolfo" with the author's corrections and margin notes. After examining the item, he discovered that it was actually by Mary Shelley with slight corrections by Hunt and Shelley. A few years later, Brewer purchased an unpublished Hunt manuscript, "Sonnets by the Italian Poets With Notes", and was later disappointed to find it had actually been written (copied) by Hunt's son, Thornton. For all collectors, Brewer offered the practical advice, caveat emptor. ${ }^{26}$

In closing The Joys and Sorrows of a Book Collector (a positive work that actually contains more "joys" than "sorrows"), the collector addressed all those so-called "philistines" who continually asked him about and could not understand his motivations for collecting. For Brewer, "The fun of collecting and the joy of possession are the only rewards a book collector

\footnotetext{
${ }^{26}$ Ibid., 17, 26, 29-36.
} 
should seek." Books and manuscripts contained an intrinsic value and were valued by him because of that and not, as his writings show clearly, as mere investments or status symbols. His hobby brightened his life and "has brought me joy daily, and its further pursuit will cheer the years that are left to me." 27 In 1929, in Some Letters From My Leigh Hunt Portfolios, Brewer offered another Christmas book to his friends, "another evidence of our hobby" which illuminated several items from his collection. Again, as he often did in his publications on collecting Huntiana, Brewer advocated the therapeutic value of book collecting and, really, any other hobby by urging "if you do not possess a hobby of your own, begin the new year by getting one." 28

The publication of his annual Christmas books enabled Luther A. Brewer to communicate his feelings about books and literature, reading and collecting Leigh Hunt and his circle, and the period from which the literature was produced to his friends and other aficionados. Naturally, there was a certain amount of "showing off" the collection inherent in his Christmas books and they reveal Brewer indulging in the "pleasures of possession." However, the above examination of a small, selected number of Torch Press publications (which I believe is quite representative) reveals a great deal about this collector, Brewer, and the multi-dimensional nature of the "book collecting game" during the period. His superb collection was acquired by The University of Iowa and it has continued to facilitate scholarship and research. The historic and traditional interpretation of collectors as public benefactors is maintained by Brewer's example.

The culture of collecting, though, was anchored by a dissatisfaction with the current and the contemporary. All the activities which collecting consisted of-from acquisition to reading (by the fireplace in a comfortable chair)-served as a therapeutic safety-valve that helped the collector cope with his

\footnotetext{
${ }^{27}$ Ibid., 63-64.

${ }^{28}$ Luther A. Brewer, Some Letters From My Leigh Hunt Portfolios (Cedar Rapids, IA: Torch Press, 1928), 96.
} 
sentimental perception of the negative features of a modernizing American society. While it can be argued that collecting reinforced the collector's latent alienation, this form of "escapism" did not, of course, stop "progress" or modernity. Collecting was a psychological diversion and not an outright attack. Viewing it in this way does not lessen the contributions which collectors have made or trivialize collecting itself but, rather, aims at a more complete understanding of how some members of the middle and upper-classes handled cultural and societal change during the late nineteenth and early twentieth centuries.

By reading and handling his Huntiana, by finely "dressing" selected books in handsome bindings and paying homage to these cultural artifacts, by visiting the sites in London which held associational significance, and by regularly reflecting upon the "lost" world and times of Leigh Hunt, Luther A. Brewer could effectively transport himself (via his imagination) to an idealized era. The books, the manuscripts, the autograph letters, the collection and the idea of collecting itself, served to link him to the past. When one sat with Brewer "around the library table", Leigh Hunt, Charles Lamb, the Shelleys, Keats, Byron, and others crowded intimately nearby. They provided the collector comfort, security and a reassuring sense of the familiar. 